\title{
Novel Photoactive N-Heterocycles Bearing a Benzoxazole Moiety: Synthesis and Photophysical study
}

\author{
Ricardo F. Affeldt (PG)*, Dennis Russowsky (PQ), Fabiano S. Rodembusch (PQ) \\ Depto. de Quím.Orgânica UFRGS Av. Bento Gonçalves, 9500. Porto Alegre - RS. CEP 91501-970. \\ *Corresponding author: r.affeldt@gmail.com
}

Keywords: 1,4-dihydropyridines, fluorescence, benzoxazole

\section{INTRODUCTION}

The 2-(2'-hydroxyphenyl)benzoxazole (HBO) has been receiving considerable attention during the past decades concerning its application as highintense fluorescent probe. ${ }^{1}$ On the other hand, 1,4dihydropyridines (1,4-DHP) are small molecules recognized for their pronounced bioactivity as calcium channel blockers. $^{2}$ Structurally, the 1,4DHPs are biommimetic analogues of the NADH coenzyme, which has also application as fluorescent probe in biological fermentations. Herein, we describe the synthesis and photophysical study of new 1,4-DHPs bearing the fluorescent HBO moiety.

\section{RESULTS AND DISCUSSION}

In order to synthesize intense fluorescent 1,4-DHPs, a method for obtaining the precursor 5-formil-2-(2'hydroxyphenyl)benzoxazole ( $\mathrm{HBOCHO}$ ) had to be designed. The synthesis was developed in two steps consisting on condensation of 2-aminophenol and salicylic acid to afford $\mathrm{HBO}$ and further formylation step with hexamethylenetetramine yielding the desired product (Figure 1).
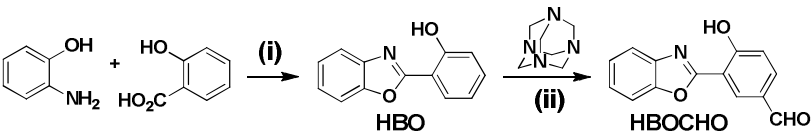

Figure 1. Synthesis of $\mathrm{HBOCHO}$. Conditions: (i) PPA, $175^{\circ} \mathrm{C}, 5 \mathrm{~h}$. Yield $57 \%$ (ii) PPA, $100^{\circ} \mathrm{C}, 4 \mathrm{~h}$. Yield $30 \%$.

The novel N-heterocycles (HBODHP) were achieved by Hantzsch multicomponent condensation catalyzed by $\mathrm{InCl}_{3} / \mathrm{SiO}_{2}$ composite ${ }^{3}$ (Figure 2).
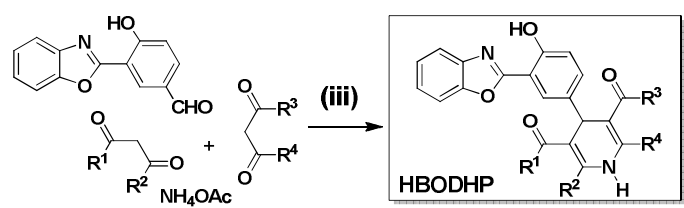

Figure 2. Multicomponent synthesis of HBO-DHPs. Conditions: (iii) $\mathrm{InCl}_{3} / \mathrm{SiO}_{2}$ (10 mol\%), $\mathrm{PrOH}$, reflux, $3 \mathrm{~h}$.

Three new fluorescent heterocycles were obtained varying ethyl acetoacetate and dimedone in different combinations (Table 1). These combinations were chosen due to similarity of the desired products with known bioactive molecules. The reaction was carried out under reflux. The catalyst and the pure product were removed from the crude mixture by simple filtration.

Table 1. Multicomponent synthesis of HBODHPs.

\begin{tabular}{|c|c|c|c|}
\hline Ent. & $\mathbf{R}^{1}$ & $\mathbf{R}^{3}$ & Yield \\
\hline 1 & OEt & OEt & $46 \%$ \\
\hline 2 & $-\mathrm{CH}_{2} \mathrm{C}\left(\mathrm{CH}_{3}\right)_{2} \mathrm{CH}_{2-}$ & $-\mathrm{CH}_{2} \mathrm{C}\left(\mathrm{CH}_{3}\right)_{2} \mathrm{CH}_{2-}$ & $50 \%$ \\
\hline 3 & OEt & $-\mathrm{CH}_{2} \mathrm{C}\left(\mathrm{CH}_{3}\right)_{2} \mathrm{CH}_{2-}$ & $66 \%$ \\
\hline
\end{tabular}

To enhance the applicability of these privileged compounds, their oxidation were performed (Figure 3) leading to a pyridine derivative (HBOPy) aiming different photophysical properties.
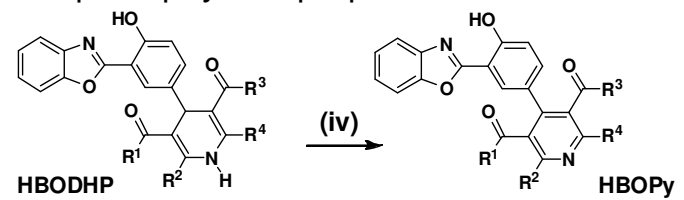

Figure 3. Oxidation of HBODHPs. Conditions: (iv) $\mathrm{I}_{2}$ 2eqv., MeCN, reflux, 5h. Yield 70-90\%.

The HBODHP (Table 1, ent. 1) presents in acetonitrile an absorption band located at $333 \mathrm{~nm}$ and a fluorescence emission located at $473 \mathrm{~nm}$. The oxidized HBODHP shows absorption and fluorescence emission maxima red-shifted $2 \mathrm{~nm}$ (335 $\mathrm{nm})$ and $14 \mathrm{~nm}(487 \mathrm{~nm})$ respectively, as expected, since the conjugation length was increased. All fluorescence results indicate that a phototautomerism takes place in the excited state.

\section{CONCLUSION}

Novel fluorescent 1,4-dihydropyridines were successfully synthesized by Hantzsch multicomponent reaction using a new benzoxazole dye. The 1,4-DHPs and its oxidized analogues presented absorption in the UV region and fluorescence emission in the blue-green region.

\section{ACKNOWLEDGEMENTS}

CNPq and INDI-Saúde for financial support.

\section{REFERENCES}

${ }^{1}$ (a) Abou-Zied, O.K. Chem. Phys. 2007, 337, 1. (b) Demchenko, A.P. et al. J. Fluor. 2010, 20, 1099.

${ }^{2}$ Bossert, F. et al. Angew. Chem. Int. Ed. Engl. 1981, 20, 762.

${ }^{3}$ Affeld, R.F.; Russowsky, D. XXXI RASBQ, 2008, Águas de Lindóia/SP. 